\title{
Perempuan dan Terorisme: Studi Literatur di Indonesia
}

\author{
Achievinna Mirza Senathalia ${ }^{1}$, Nurjanah $^{2}$ \\ Universitas Islam Negeri Syarif Hidayatullah Jakarta ${ }^{1}$, Universitas Negeri Padang ${ }^{2}$, \\ Indonesia \\ Corresponding Author, email: achievinna20@mhs.uinjkt.ac.id
}

\begin{abstract}
The focus of this article discusses the development of literature on the theme of women and terrorism in Indonesia. Primary data in the form of scientific articles obtained from online sources such as online journals were analyzed using qualitative descriptive methods. The findings of this article show that there are many studies and articles published with various focuses or topics related to the themes of women and terrorism. Studies related to women and terrorism in Indonesia can be classified covering topics of women's involvement, women's roles, women's absence, media, and gender. Therefore, this article confirms that the study of women and terrorism is growing and diversified along with the increasing phenomenon of women's terrorism.
\end{abstract}

Keywords: Women, Terrorism, Literature Study, Indonesia

This is an open-access article distributed under the Creative Commons 4.0 Attribution License, which permits unrestricted use, distribution, and reproduction in any medium, provided the original work is properly cited. $\bigcirc 2018$ by author.

\section{Pendahuluan}

Meskipun terorisme setua umat manusia, namun peristiwa baru-baru ini di seluruh dunia telah menunjukkan ancaman bagi masa depan dunia saat ini bukan hanya senjata nuklir, invasi dan kudeta militer, namun juga keterlibatan perempuan dalam terorisme dan organisasi teroris (Agara, 2015). Di sisi lain, kenyataan keterlibatan perempuan dalam aksiaksi terorisme memunculkan berbagai pertanyaan subtantif seperti tentang motivasi perempuan apakah mereka berpartisipasi dengan alasan agama, politik atau pribadi dan lainlain. Di luar itu, fenomena terorisme dua dekade awal abad 21 memperlihatkan perubahan gerakan dan aksi-aksi teroris yang semakin melibatkan perempuan dalam aksi-aksinya. Hal ini antara lain dibuktikan gejala terorisme di Indonesia yang dalam beberapa kasus melibatkan perempuan.

Seiring dengan fenomena tersebut, kajian-kajian terkait tema terorisme yang dilakukan oleh para peneliti juga semakin banyak berkembang dan beragam. Bukan hanya itu, perkembangan kajian terkait terorisme juga ditandai dengan tumbuh dan berkembangnya lembaga-lembaga pusat studi terorisme di dunia, terutama di Indonesia. Sejalan dengan dinamika ini, fokus bahasan artikel ini adalah perkembangan kajian-kajian para sarjana tentang tema perempuan dan terorisme. Artikel ini memandang dekade terakhir ini kajian tentang tema perempuan dan terorisme semakin banyak seiring dengan semakin meningkatnya kasus-kasus terorisme yang melibatkan perempuan.

Ada banyak riset ilmiah baik berupa tesis, disertasi, dan artikel-artikel ilmiah telah membahas tema tersebut dengan berbagai variabel sebagai objekt. Jurnal Perspectives on Terrorism (April 2020) yang diterbitkan oleh Terrorism Research Initiative, mepublikasikan daftar bibliografi tentang perempuan dan terorisme yang tidak kurang dari 48 halaman dengan topic-topik bahasan yang beragam. Akibatnya, hampir bisa dipastikan tak ada celah untuk kajian-kajian baru yang mungkin dilakukan oleh sarjana yang datang kemudian, kecuali hanya menunjukkan objek-objek baru dari berbagai kasus di belahan dunia. Di sisi 
lain, kajian-kajian yang banyak dan berserakan tentang perempuan dan terorisme perlu dikonstruk tipologinya sehingga terpetakan dengan baik. Berdasarkan alasan ini dan asumsi di atas, artikel ini melakukan survey dan memetakan kajian-kajian terkait perempuan dan terorisme.

Untuk kepentingan tujuan tersebut, artikel ini menjadikan media online atau internet sebagai sumber data dengan teknik pengumpulan via google scholar $\mathrm{d}$ a $\mathrm{n}$ a ta kunci "perempuan dan terorisme." Dengan cara ini, ditemukan dan dikumpulkan beberapa artikel ilmiah yang dipublikasi secara online dalam berbagai jurnal di Indonesia dan di luar negeri. Meski begitu, dapat dipastikan bahwa kajian-kajian tentang perempuan dan terorisme sebenarnya telah banyak dilakukan oleh para sarjana dan peneliti di berbagai negara dan dunia secara global. Namun, akibat keterbatasan akses dan lain hal, kajian artikel ini hanya fokus pada data sejauh yang ditemukan berdasarkan metode dan teknik yang telah dikemukakan di atas.

\section{Metode}

Penelitian ini merupakan penelitian kualitatif dengan kajian kepustakaan (library research) dimana penelitian ini berusaha menggambarkan fenomena-fenomena yang ada, yang berlangsung saat ini atau saat yang lampau. Data primer berupa artikel-artikel ilmiah diperoleh dari sumber online seperti jurnal online yang dianalisis dengan metode deskriptif kualitatif. Metode analisis deskriptif dilakukan dengan cara mendeskripsikan fakta-fakta yang kemudian disusul dengan analisis, tidak sematamata menguraikan, melainkan juga memberikan pemahaman dan penjelasan secukupnya. Jenis data yang digunakan penulis dalam penelitian ini adalah data yang diperoleh dari studi literatur. Studi literatur adalah cara yang dipakai untuk menghimpun data-data atau sumber-sumber yang berhubungan dengan topik yang diangkat dalam suatu penelitian.

\section{Hasil dan Pembahasan}

\section{A. Fenomena Terorisme Perempuan}

Mengutip dari Azra, cendekiawan Indonesia ini dalam artikel yang dimuat republika.com, menyatakan bahwa fenomena ekstremisme, radikalisme, dan terorisme di Indonesia kian melibatkan banyak perempuan. Perempuan yang terlibat juga tergolong masih berumur 20-an tahun (Saputro, 2010, pp. 211-228). Keterlibatan perempuan dalam aksi terorisme pada waktu terakhir terjadi dalam peristiwa bom bunuh diri di depan Katedral Makassar (28/3/2021) (Rahma, 2021). Dalam kasus ini, YSF bersama suaminya L, tewas dalam ledakan bom. Perempuan kedua, gadis ZA yang tewas ditembak aparat Polri di Mabes Polri Jakarta setelah mengacung-acungkan pistol 'soft-gun' pada beberapa petugas di depan pos keamanan (Adimaja, 2021). Perkembangan ini memperlihatkan ekstremisme dan radikalisme yang dapat berpuncak pada aksi terorisme tidak hanya bisa dilakukan oleh lakilaki, tapi juga perempuan (Azra, 2021).

Secara historis pada konteks lebih luas, keterlibatan perempuan dalam aksi terorisme bukan hal baru (Mulia, 2019, pp. 80-95). Para pelaku juga tak terbatas pada perempuan dari agama tertentu. Perempuan berlatar belakang agama atau lingkungan sosial-politik berbeda dapat menjadi teroris. Perempuan yang agaknya pertama kali tercatat sebagai pelaku terorisme adalah Vera Zasulich. Pada Januari 1878, dia memberondong senapannya ke Gubernur St Petersburg, Rusia, Fyodor Trepov yang kemudian tewas karena luka-luka yang dia derita (Mulia, 2019, pp. 80-95). Di dalam sidang pengadilan, Vera dengan bangga menyatakan diri bukan pembunuh, tetapi 'teroris' yang berjuang melawan kesewenangwenangan politik Rusia (Azra, 2021). 
Keterlibatan perempuan dalam terorisme awalnya terkait politik (W.kusuma, 2002). Keterkaitan perempuan dengan terorisme dan politik sangat kompleks dan ekstensif, khususnya sejak 1960-an yang disebut sebagai awal peningkatan aktivisme teroris perempuan. Perempuan yang terlibat aksi terorisme pada dasawarsa 1960-1970, umumnya berasal dari lingkaran politik sayap kiri. Ada beberapa contoh aktivis perempuan yang kemudian menjadi pola dasar (prototipe) aksi terorisme (Azra, 2021). Yang paling menonjol misalnya, Ulrike Meinhof, teroris sayap kiri dan salah satu pendiri Red Army Jerman, yang terlibat aksi teror dan perampokan bank (heist) antara 1970-1972. Dia dijatuhi hukuman penjara delapan tahun pada 1974; tapi dia bunuh diri di penjara sebelum terlalu lama menjalani hidup di 'hotel prodeo' (Oktorino, 2013).

Perempuan juga terlibat aksi terorisme dalam konflik politik berbau agama (Protestan versus Katolik) di Irlandia Utara (Kennedy, 2019). Dua teroris perempuan sering disebut: Dolours dan adiknya Marian Price yang melakukan pengeboman di Old Bailey, London, pada 8/3/1973 yang membuat lebih 200 orang luka dan satu tewas (Azra, 2021). Menurut Azra, perempuan Indonesia mulai terlibat kelompok teroris sejak 2003. Hal ini didasarkan pada beberapa perempuan Indonesia yang menjadi istri Nurdin M.Top (teroris asal Malaysia). Namun, seiring waktu, jumlah keterlibatan perempuan dalam aksi terorisme semakin meningkat. Merujuk pada laporan Instite for Policy Analysis and Conflict (IPAC 2020), Azra mengungkap sekitar 49 perempuan terlibat sejak 2003 (Musfia, 2017).

Keterlibatan mereka dalam aksi terorisme dapat diklasifikasi menjadi tiga kategori: pertama, terlibat karena membantu suami atau keluarga. Kedua, terlibat sebagai aktivis yang turut memainkan peran pendukung penting dalam aksi terorisme. Ketiga, sebagai aktor utama pelaku terorisme. Namun, pada awal sejarahnya, keterlibatan perempuan adalah sebagai pelengkap penyerta dair confirmed teroris. Selanjutnya baru bertahap mereka memainkan perang penting dalam sel terorisme, hingga para tahapan sebagai aktor utama. Selain itu, motif keterlibatan perempuan dalam aksi terorisme juga mengalami perkembangan (Solihah, 2020). Azra mengungkap awalnya mereka motif terorisme global adalah politik, namun sejak tahun 2000-an motif sudah melibatkan motif keagamaan (Azra, 2021). Motif terakhir ini lazim karena berdasarkan pemahaman dan praksis keagaman literal yang kemudian menghasilkan ekstremisme dan radikalisme (Adina \& Lestari, 2018, pp. 298-305).

\section{B. Tipologi Kajian Tentang Perempuan dan Terorisme di Indonesia}

Sebagaimana telah disinggung di awal, aksi-aksi terorisme yang melibatkan perempuan telah menjadi fenomena sosial dan politik di dunia secara global, khususnya di Indonesia. Akibat dari fenomena ini, para sarjana dan intelektual telah berupaya dengan serius mengkaji masalah tersebut sehingga melahirkan buku dan karya ilmiah yang sangat banyak dan komplek. Jurnal Perspectives on Terrorism (April 2020) yang diterbitkan oleh Terrorism Research Initiative, mepublikasikan daftar bibliografi tentang perempuan dan terorisme yang tidak kurang dari 48 halaman dengan jumlah minimal daftar tidak kurang dari 20 referensi perhalaman. Daftar tersebut dengan demikian memuat ratusan referensi yang terdiri dari artikel jurnal, bab buku, buku, jilid yang diedit, tesis, tentang perempuan dan terorisme.

Perkembangan yang sama juga terjadi di Indonesia. Sejak terorisme menjadi isu global, khsusnya terkait tema perempuan dan terorisme, telah memunculkan banyak kajian oleh akademisi baik yang dipublikasikan maupun yang belum dipublikasikan. Untuk kepentingan artikel ini, perkembangan literasi tentang tema tersebut ditunjukkan yang telah dipublikasi pada jurnal yang bisa diakses secara online. Hal ini tidak menafikan banyak disertasi dan tesis di berbagai Universitas dan lembaga-lembaga studi terorisme yang ada di Indonesia seperti Pusat Studi Terorisme di Universitas Indonesia. 
Terlepas dari yang tak disebutkan, adapun kajian-kajian yang dapat diakses terkait tema perempuan dan terorisme dapat dipetakan meliputi topik keterlibatan perempuan, peran perempuan, gender, dan dampak media sosial. Kerangka-kerangka studi tersebut adalah sebagai berikut:

\section{Studi Keterlibatan Perempuan dalam Terorisme}

Studi tentang perempuan dan terorisme tentu dimulai dengan kajian tentang keterlibatan perempuan secara umum. Salah satu model kajian ini misalnya adalah yang dilakukan oleh Margaret Gonzalez-Perez tahun 2008 lalu. Fokus kajian Margaret GonzalezPerez (2008) adalah hubungan antara perempuan dan kegiatan teroris di era pasca-Perang Dunia IIv (Margaret Gonzalez-Perez, 2009). Organisasi teroris domestik menurutnya menggunakan revolusi, pemisahan diri, atau cara lain untuk mengubah aspek internal negara dan struktur sosial dan ekonomi. Gonzalez-Perez berpendapat kurangnya partisipasi perempuan dalam kegiatan ini mencerminkan fakta bahwa perempuan diturunkan ke status quo, terlepas dari keberhasilan atau kegagalan gerakan teroris internasional.

Berikutnya adalah kajian yang dilakukan oleh V.G. Julie Rajan (2011). Julie Rajan menawarkan evaluasi pelaku bom bunuh diri perempuan melalui kerangka pasca-kolonial, Dunia Ketiga, feminis, dan hak asasi manusia, dengan mengambil studi kasus dari konflik di Palestina, Sri Lanka, dan Chechnya. Eksplorasi laporan budaya, media, dan politik dari berbagai geografi menyajikan informasi yang berbeda tentang potret wanita dan pelaku bom bunuh diri yang sama. Mayoritas media Barat dan negara-negara berdaulat yang terlibat dalam perang melawan kelompok-kelompok yang melakukan pengeboman cenderung berfokus pada kondisi mental abnormal pengebom perempuan; seperti kuku mereka yang dicat atau mata mereka yang indah; seksualitas mereka; dan berbagai cara dimana mereka telah dikorbankan oleh budaya Dunia Ketiga yang terbelakang, terutama oleh "Islam".

Sebaliknya, propaganda yang dihasilkan oleh kelompok pemberontak yang mengerahkan pembom wanita, budaya yang mendukung kampanye tersebut, dan pemerintah negara-negara yang berperang dengan negara-negara berdaulat dan negara-negara Barat cenderung memproyeksikan pembom wanita sebagai pahlawan mitos, dengan cara yang menggantikan operasi kesyahidan pembom pria. Banyak dari buku-buku yang diterbitkan tentang fenomena ini telah mengungkap cara-cara menarik untuk membaca subjektivitas pelaku bom perempuan, tetapi tidak mengeksplorasi fenomena pelaku bom perempuan baik di dalam maupun di luar aktivitas militannya, atau bertentangan dengan budaya dan teoretis patriarki, Orientalis, dan feminis Barat. Kerangka kerja yang melabeli pembom perempuan terutama sebagai korban budaya terbelakang. Sebaliknya, buku ini menawarkan lensa korektif terhadap wacana yang ada, dan mendorong evaluasi yang lebih berimbang terhadap perempuan pengebom dalam konflik kontemporer.

Studi berikutnya tentang keterlibatan perempuan dilkukan oleh I Made Redi Hartana (2017). Ia menulis dan menegaskan teroris perempuan sebagai ancaman faktual di Indonesia. Ia menyebut bahwa ada pergeseran peran perempuan dari femenis ke maskulin dalam kasus teroris. Hal ini menurutnya tak lepas dari pengaruh jaringan internasional dan perkembangan teknologi informasi (Hartana, 2017). Sejalan dengan studi Made Redi Hartana, setahun kemudian Moh Rasyid (2018) mempublikasikan artikel berjudul "Perempuan dalam Jaringan Radikalisme vis a vis Terorisme Global." Dalam artikel tersebut, Rasyid mengekplorasi tentang perempuan dalam kerangka jaringan radikal global yang mengatasnamakan Islam sebagai basis perjuangannya. Penelitian ini menggunakan pendekatan kualitatif, dengan sumber data dari media massa maupun media elektronik (Koran, Televisi, Media Sosial, dan lain-lain) (Rosyid, 2018). 
Hasil penelitian Rasyid menunjukan bahwa keterlibatan perempuan dalam gerakan teroris teridentifikasi sejak tahun 1970-an. Perempuan menjadi pelaku pengeboman setelah dicuci otaknya oleh teroris lelaki. Faktor yang menyebabkan keterlibatan kaum perempuan, yaitu: 1) sebagai pelarian akibat perlakuan diskriminatif yang menimpanya; 2) alasan kepedulian terhadap ketimpangan yang diderita masyarakat muslim global; 3) kesadaran beragama yang sempit sehingga dengan menjadi pelaku teroris mereka merasa mendapatkan posisi sosial yang setara dengan teroris lelaki dalam berjihad; 4) psikologis yang sedang labil karena ada masalah, dan mereka berselancar di media sosial, sehingga rentan terjebak menjadi pelaku terror dan; 5) perempuan yang suaminya menjadi teroris dilibatkan pula sebagai teroris. Strategi yang dilakukan kelompok teroris dalam menaklukkan perempuan adalah dengan menikahi mereka (Rosyid, 2018).

Udji Asiyah dkk. (2020) juga melakukan kajian yang sama, yakni fokus pada tema Jihad Perempuan dan Terorisme. Artikel mereka yang dipublikasikan pada Jurnal Sosiologi Agama menelaah sejauh mana keterlibatan perempuan dalam kasus bunuh diri yang menurut mereka ditentukan oleh bagaimana perempuan memaknai jihad dan orientasi tindakannya serta dominasi patriarkhi yang melingkupinya. Kasus bom bunuh diri perempuan yang terkait dengan terorisme dan diberitakan dalam berbagai media dapat memberikan informasi tentang hubungan antara konsep agama, orientasi tindakan dan dominasi patriakhi. Analisis Udji Asiyah dkk. mengungkapkan bahwa keterlibatan perempuan dalam kasus terorisme tidak telepas dari persoalan pemberian makna terhadap konsep agama dan orientasi tindakan serta dominasi patriakhi (Asiyah, Prasetyo, \& Sudjak, 2020).

Siti Rodiah membahas tentang latar belakang dari pelibatan perempuan dalam aksi terorisme, motivasi, peran, dan upaya penanggulangannya. Peran perempuan dalam gerakan terorisme mengalami transformasi, dimana awalnya hanya sebatas pendukung yang membantu menyiapkan kebutuhan dalam melakukan aksi teror. Namun, kemudian perempuan menempati posisi-posisi strategis dalam aksi terorisme, seperti pemimpin kelompok, perekrut, hingga pelaku bom bunuh diri atau ancaman kekerasan yang memiliki resiko lebih tinggi daripada peran sebelumnya. Beberapa alasan yang melatarbelakangi transformasi ini menurut Siti Rodiah adalah paham radikal terhadap suatu keagamaan yang menimbulkan tindakan ekstrem seperti terorisme.

Selain itu, rasa ketidakadilan, ketimpangan sosial ekonomi, dan merasa didiskriminasi oleh keadaan juga menjadi faktor tumbuhnya rasa amarah dan perlawanan terhadap pemerintah atau pemangku kepentingan. Dalam pandangan Iik Hikmatul Hidayat, kelompok ini biasanya memanfaatkan kelemahannya serta isu ketidakadilan dan ketidaksetaraan, dengan begitu perempuan mudah direkrut dalam jaringan terorisme. Korban dari ideologi suami atau keluarga, korban indoktrinasi agama yang tidak memihak kemanusiaan, korban stigmatisasi dari masyarakat, korban media, dan juga korban dari ekses konflik. Perempuan lagi-lagi hanyalah korban dari kondisi yang diciptakan oleh para elit kekuasaan patriarki.

\section{Peran Perempuan Terkait Terorisme}

Tema perempuan dan terorisme utamanya meninjau aspek peran perempuan terkait aksi-aksi terorisme. Namun, studi tentang hal ini terbagi pada dua dimensi yaitu peran perempuan bukan terorisme dan peran perempuan terkait dan terlibat dalam terorisme. Topik terakhir ini misalnya dapat ditemukan dalam artikel Umi Najikhah Fikriyati (2017) dan Nesa Wilda Musfia (2017). Artikel Umi Najikhah Fakriyati fokus pada tema perempuan dan deradikalisme. Dalam konteks ini, ia mengkaji peran perempuan dengan menelaah peran istri mantan teroris dalam deradikalisasi. Sementara fokus kajian Nesa Wilda Musfia menelaah 
peran perempuan dalam jaringan terorisme ISIS di Indonesia. Adapun kajian tentang peran perempuan bukan terorisme dapat dilihat pada artikel Adang Darmawan Achmad (2021). Ia secara umum menelaah peran perempuan dalam pencegahan radikalisme.

Sebuah penelitian menyebutkan bahwa dengan menggunakan pendekatan fenomenologi menunjukkan bahwa istri memiliki peran dalam menderadikalisasi para suami sehingga tidak lagi terlibat dalam aksi terorisme. Proses deradikalisasi telah dimulai ketika suami menjalani hukuman di lembaga pemasyarakatan, yaitu dengan cara melakukan kunjungan rutin ke lembaga pemasyarakatan. Selain itu, istri juga berusaha tidak bergantung secara ekonomi kepada suami, Hal ini secara tidak langsung menjauhkan suami dari kelompok yang diikutinya. Atas dasar itu, riset ini menyimpulkan bahwa deradikalisasi berbasis keluarga dinilai lebih efektif dan pendekatan tersebut dapat melengkapi pendekatan deradikalisasi yang selama ini telah berjalan (Fikriyati, 2015).

Berbeda dengan simpulan kajian tersebut, simpulan kajian lain yang menelaah peran perempuan dalam jaringan terorisme ISIS di Indonesia menunjukkan bahwa jaringan terorisme ISIS di Indonesia mulai melibatkan perempuan pada posisi-posisi tertentu. Hal ini menurutnya dibuktikan dengan kasus kelompok radikal MIT di bawah pimpinan Santoso yang melibatkan istri-istri pejuangnya dan juga jaringan ISIS Solihin yang telah melibatkan perempuan sebagai pelaku bom bunuh diri (Musfia, 2017).

Peran yang ditempati perempuan jaringan ISIS di Indonesia di antaranya ada pada level follower yaitu sebatas simpatisan atau financial sponsor, recruiter, level middle management, hingga pelaku terror bom bunuh diri. Secara general peran perempuan tersebut dibagi menjadi empat yaitu pendukung tidak langsung, pendukung langsung, pelaku bom bunuh diri dan pemimpin dalam kelompok. Adapun kajian berikutnya menyatakan bahwa seorang perempuan berperan penting dalam pencegahan kekerasan jika perempuan tersebut mampu membangun lingkungan kehidupan keluarga yang harmonis dan senantiasa menekankan norma-norma keagamaan yang baik dan moderat sesuai dengan ajaran (Achmad, Qotadah, Abdul Aziz, \& Al Anshary, 2021, pp. 2657-2125).

\section{Ketidakhadiran Perempuan dalam Terorisme 2009-2015}

Studi tentang tema perempuan dan terorisme salah satunya juga fokus pada persoalan ketakhadiran perempuan dalam aksi terorisme. Model kajian ini dapat ditemukan pada tulisan Robiatus Sholukhah (2019) yang dipublikasikan pada Journal of International Relations. Dalam artikelnya membahas ketidakhadiran perempuan dalam aksi teroris di Indonesia antara tahun 2009-2015. Berdasarkan analisisnya menegaskan bahwa ketidakhadiran female suicide terrorism (FST) di Indonesia tahun 2009-2015 disebabkan oleh tiga faktor. Pertama adalah faktor agensi perempuan dalam pandangan kelompok teroris di Indonesia. Adanya kesamaan pandangan yang dianut oleh kelompok teroris di Indonesia mengenai perempuan yang harus dilindungi sehingga para laki-laki dalam kelompok teroris di Indonesia tidak mau melibatkan perempuan khususnya istrinya ke dalam bahaya (Robiatus, 2019).

Faktor kedua adalah ijihad hanya dilakukan oleh laki-laki dewasa. Hal tersebut karena adanya pandangan bahwa perempuan kurang mampu menjaga rahasia. Oleh karena itu, perempuan sama sekali tidak dilibatkan dalam urusan operasional maupun militer JI, karena standar keamanan JI sebagai tandzim sirri (organisasi rahasia) melarang anggotanya untuk membocorkan rencana aksi mereka kepada siapa pun, termasuk istri dan anak mereka sehingga jihad hanya dilakukan oleh laki-laki. Ketiga, kelompok terorisme di Indonesia seperti JI dan JAT tidak banyak melibatkan perempuan dalam pelaksanaan misinya. Hal ini dikarenakan prinsip anggotanya yang mirip dengan konsep tradisi Jawa, bahwa perempuan 
berada pada ranah domestik yaitu pada urusan "masak-macak, dan macak" sedangkan lakilaki berperan pada ranah publik. Selain itu, terdapat kepercayaan bahwa perempuan memang tidak seharusnya mencampuri urusan laki-laki. menggunakan teori konstruktivisme feminis dan konsep perempuan dalam budaya Jawa.

Kontruktivisme feminis adalah teori hubungan internasional yang dibangun di atas teori konstruktivisme. Teori ini berdasarkan pada pemikiran bagaimana gender mempengaruhi politik global (Baylis et all 2008). Dalam melihat perempuan yang menjadi aktor teror atau pelaku FST, jika melihat culture masyarakat Indonesia saat ini masih cukup lekat dengan konstruk patriarki dan interpretasi tradisional teks-teks Islam dimana posisi perempuan berada di bawah laki-laki (Marcoes 2015). Perempuan lemah, keibuan, emosional, irasional, dan tidak punya hak katas keputusannya sendiri. Perempuan menjadi konco wingking, manut katut dengan laki-laki sebagai pemimpin. Narasumber dalam penelitian ini yaitu Deni Suramto, Abdul Ghoni dan Suami dari Marhama yaitu Ikhsan Andriyanto ketiganya adalah narapidana terorisme yang berasal dari Solo. Selain Solo terdapat nama Ika Puspitsari yaitu seorang wanita Jawa yang berasal dari Purworejo.

\section{Integrasi Gender dan Terorisme}

Perkembangan kajian terkait tema perempuan dan terorisme juga ditandai dengan upaya pengintegrasian tema gender. Perspektif dan model kajian ini antara lain dapat dilihat dari artikel T.Agara (2015) yang fokus pada tema perempuan, gender, dan terorisme. Contoh lain adalah tulisan Nava Nuraniyah dan Ihsan Ali Fauzi (2017) yang menekankan perspektif gender dalam studi- studi tentang Kekerasan Teroris di Indonesia. Hal yang sama juga terlihat pada artikel yang ditulis oleh Musdah Mulia (2018) dan Achievinna Mirza Senathalia (2021). Musdah Mulia menekankan pada perempuan yang terlibat dalam aksi terorisme adalah sebagai korban, sementara Achievinna mencoba mengkritik fenomena terorisme perempuan sebagai sesuatu yang bertentangan dengan perpektif gender dan femenisme (Senathalia, Subhan, \& Rosyidah, 2021)

Sjoberg, L., \& Gentry, C., E. (eds)., dalam Women, gender and terrorism (2011) menyebutkan dekade terakhir dunia menyaksikan peningkatan partisipasi perempuan dalam terorisme (Sjoberg, L., \& Gentry, C., 2011). Sebagian besar abad kedua puluh, jarang terdengar tentang teroris perempuan. Namun, perempuan semakin berperan aktif dalam melakukan aksi bom bunuh diri, pembajakan pesawat, dan penyanderaan di tempat-tempat seperti Palestina, Irak, Afghanistan, Sri Lanka, Lebanon, dan Chechnya. Teroris perempuan menjadi subyek dari sejumlah besar media dan perhatian ilmiah, tetapi analisis perempuan, gender, dan terorisme jarang dan penuh dengan pemikiran stereotip tentang kemampuan dan motivasi perempuan. Namun, mereka dalam karya tersebut mengeksplorasi hubungan perempuan dengan terorisme yang berfokus pada dinamika politik, gender, ras, dan budaya dunia kontemporer. Pembahasan dalam Women, gender and terrorism menawarkan gambaran tentang partisipasi perempuan dalam hubungannya dengan terorisme kontemporer. Satu bab misalnya membahas sejarah keterlibatan mereka dalam politik dan konflik masyarakat Islam. Bagian selanjutnya mencakup analisis empiris dan teoritis gerakan teroris di Chechnya, Kashmir, Palestina, dan Sri Lanka. Bagian ketiga membahas tentang keterlibatan perempuan dalam al-Qaeda.

Tunde Agara dalam artikelnya Gendering Terrorism: Women, Gender, Terrorism and Suicide Bombers menekankan bahwa masyarakat harus berhenti memperlakukan para wanita yang terlibat dalam bom bunuh diri sebagai penyimpangan-penyimpangan semata. Jika demikian, maka teroris akan terus mengeksploitasi perempuan manakala terus dilihat sebagai kaum lemah dari perspektif gender. Tunde Agara juga menekankan seperti 
pengamatan Sjoberg bahwa terlepas dari jenis kelamin atau gender, teroris tidak selalu memiliki kebebasan penuh untuk memilih atau bertindak dan sebaliknya sebagian bergantung pada pilihan dan tindakan orang lain. Pelaku terorisme bunuh diri memiliki derajat tindakan/perbuatan mereka dan justifikasi yang mereka tawarkan tidak sejajar dengan berbagai penjelasan yang ditawarkan oleh para analis Barat (Agara, 2015).

Gagasan integrasi gender sebagai salah satu perspektif analisis juga dikemukakan oleh peneliti lainnya, dimana mereka melihat meningkatnya keterlibatan perempuan dalam aksiaksi terorisme di dunia, termasuk terorisme bunuh diri, telah mendorong dimasukkannya perspektif gender dalam studi-studi tentang terorisme. Hal ini dimaksudkan untuk memahami akar-akar, proses dan makanisme keterlibatan kaum perempuan yang biasanya dipersepsikan lemah lembut dan anti-kekerasan, yang pada gilirannya berguna untuk mencegah atau menghentikannya. Sayangnya menurut mereka, perkembangan positif tersebut belum di ikuti di Indonesia, meskipun laporan media populer dan studi mengenai terorisme tumbuh subur belakangan ini, seperti juga keterlibatan perempuan di dalamnya (Fauzi, 2017).

Mereka mengkritik keterlambatan tersebut, sambil menawarkan beberapa arah yang bisa ditempuh untuk mulai mengatasinya, terutama terkait dengan keterbatasan akses kepada narasumber dan bias atau prasangka yang memengaruhi penilaian para peneliti terhadap para subyek mereka. Pembasan mereka mencakup sejarah keterlibatan perempuan dari masa perang hingga terorisme bunuh diri. Dalam hal ini, mereka menunjukkan keterlibatan perempuan yang bersifat atau berdimensi kekerasan terlepas dari konteksnya seperti kasus Cut Nyak Dhien di Aceh dan Indonesia. Sejumlah fakta sejarah yang ditunjukkan tampaknya ingin membuktikan bahwa persepksi perempuan jauh dari dunia kekerasan adalah kurang tepat. Memang fitrah perempuan adalah lemah lembut dan sebagainya, namun fakta-fakta sejarah tersebut adalah bukti bahwa perempuan juga bisa terlibat dalam kekerasan, termasuk aksi-aksi terorisme. Fenomena aktual yang mereka angkat adalah kasus yang terjadi di Palestina dimana terdapat kasus perempuan, yakni Wafa Idris, melakukan bom bunuh diri (2002). Begitu juga mereka tak melupakan peristiwa-peristiwa di Indonesia yang melibatkan perempuan. Apa yang ingin ditegaskan adalah perlunya pendekatan gender dalam memahami dan menanggulangi serta menimalisir keterlibatan perempuan.

Musdah Mulia menguak berbagai hal terkait keterlibatan perempuan Muslim dalam gerakan terorisme di Indonesia. Di antaranya, menggali latar-belakang kehidupan mereka, apa motif utama mereka terlibat dalam aksi-aksi terorisme, mengapa gerakan yang penuh kekerasan dan mematikan ini justru menarik bagi kelompok perempuan yang umumnya secara bias gender masih dipersepsikan sebagai kelompok rentan dan makhluk domestik.Sesuai kodratnya, perempuan lebih mudah direkrut menjadi agen perdamaian (agent of disengagement). Kalau mereka bisa direkrut menjadi teroris seharusnya lebih mudah mengajak mereka menjadi agen perdamaian. Karena secara alami perempuan diciptakan dengan sebuah rahim untuk merawat keberlangsungan kehidupan manusia. selain itu, Musdah juga menegaskan modus baru dalam aksi terorisme menjadikan perempuan sebagai pelaku. Kalau sebelumnya aksi-aksi teror berwajah maskulin dan menggunakan pendekatan patriarkal, belakangan aksi-aksi terror memanfaatkan perempuan sebagai pelaku dan dengan pendekatan feminin. Meskipun faktanya perempuan adalah pelaku, hakikinya mereka tetap korban (Mulia, 2019).

\section{Media dan Terorisme}

Bentuk lain dari kajian tema tentang perempuan dan terorisme adalah dimensi media. Model kajian ini berupaya menggali peran manipulasi informasi terhadap keikutsertaan perempuan dalam gerakan terorisme. Secara spesifik artikel Teddy Indra Wijaya membahas 
peningkatan fenomena keterlibatan perempuan dalam ISIS ataupun kelompok teroris lain yang dikaitkan dengan penggunaan manipulasi informasi dan propaganda. Dengan menggunakan teori komunikasi, khususnya agenda setting, framing, dan propaganda yang dilakukan ISIS untuk menjelaskan penggunaan manipulasi informasi yang membentuk persepsi dan memperkuat motivasi perempuan untuk ikut terlibat dalam kelompok teroris. ISIS mengunakan spectrum menyeluruh dari propaganda yang bersifat komprehensif, kohesif, dan multidimensional. ISIS memanfaatkan secara optimal strategi propaganda yang menarik bagi perempuan yang kemudian mendorong keputusan perempuan bergabung (Wijaya, 2020, pp. 2722-1512).

\section{Kesimpulan}

Sejauh penelusuran data yang ditemukan dan pemetaan kajian-kajian tentang perempuan dan terorisme di Indonesia di atas, artikel ini menunjukkan lima aspek dan dimensi pengkajian tema tersebut telah dilakukan sejauh ini. Topik-topik yang merupakan aspek dan dimensi kajian tersebut mencakup studi keterlibatan perempuan secara umum, peran perempuan dalam penanggulangan terorisme, integrasi gender, dan studi pengaruh media sosial terkait terorisme. Aspek dan dimensi kajian ini dapat dikatakan relative masih sedikit atau kurang. Konsekuensinya adalah masih banyak ruang terbuka bagi peneliti guna melakukan pengkajian tentang tema perempuan dan terorisme di Indonesia. Dengan demikian, asumsi-asumsi dan premis-premis yang dikemukakan dalam bagian pendahuluan artikel ini bahwa semakin banyak kajian, semakin sempit dan terbatas ruang penelitian tentang perempuan dan terorisme tidaklah sepenuhnya benar. Meski begitu, klaim bahwa pengkajian tentang tema perempuan dan terorisme semakin meningkat dan berkembang seiring dengan meningkatnya fenomena dan kasus-kasus terorisme yang melibatkan perempuan sejauh ini dapat dibuktikan dalam artikel ini.

\section{Daftar Kepustakaan}

Achmad, A. D., Qotadah, H. A., Abdul Aziz, M. S., \& Al Anshary, A. A. (2021). Peran Perempuan dalam Pencegahan Kekerasan Terorisme dan Radikalisme. ADLIYA: Jurnal Hukum Dan Kemanusiaan, 15(2), 1-16. https://doi.org/10.15575/adliya.v15i2.9244

Adimaja, M. (2021). Pelaku Teror Mabes Polri Bawa Airsoft Gun, Senjata Apa Itu? Retrieved November 25, 2021, from Kompas.com website: https://www.kompas.com/sains/read/2021/04/01/170200823/pelaku-teror-mabespolri-bawa-airsoft-gun-senjata-apa-itu-?page $=$ all.

Adina, N., \& Lestari. (2018). Dukungan Keluarga dalam Upaya Membangun Kepercayaan Diri Mantan Teroris. Interaksi Online, 6(4).

Agara, T. (2015). Gendering Terrorism: Women, Gender, Terrorism and Suicide Bombers. International Journal of Humanities and Social Science, 5(6).

Asiyah, U., Prasetyo, R. A., \& Sudjak, S. (2020). Jihad Perempuan Dan Terorisme. Jurnal Sosiologi Agama, 14(1), 199. https://doi.org/10.14421/jsa.2020.141-08

Azra, A. (2021). Perempuan dan Terorisme (1). Retrieved November 25, 2021, from Republika website: https://www.republika.id/posts/15626/perempuan-dan-terorisme1

Fauzi, I. A. (2017). Kebebasan, toleransi, dan terorisme: riset dan kebijakan agama di Indonesia. Jakarta: usat Studi Agama dan Demokrasi, Yayasan Paramadina.

Fikriyati, U. N. (2015). Perempuan Dan Deradikalisasi: Peran Para Istri Mantan Narapidana Terorisme Dalam Proses Deradikalisasi. Jurnal Sosiiologi Reflektif, 9(2), 1-29. 
Hartana, I. M. R. (2017). Teroris perempuan: ancaman faktual di Indonesia. Jurnal Ilmu Kepolisian, Oktober 20(089).

Kennedy, E. S. (2019). Pembunuhan Lyra McKee di Antara Konflik Etnopolitik Irlandia Utara. Retrieved November 25, 2021, from tirt0.id website: https://tirto.id/pembunuhan-lyra-mckee-di-antara-konflik-etnopolitik-irlandia-utara$\mathrm{dm} 48$

Margaret Gonzalez-Perez. (2009). Women and Terrorism Female Activity in Domestic and International Terror Groups (1st ed.). Routledge.

Mulia, M. (2019). Perempuan Dalam Gerakan Terorisme Di Indonesia. Al-Wardah, 12(1), 80. https://doi.org/10.46339/al-wardah.v12i1.136

Musfia, N. W. (2017). Peran Perempuan dalam Jaringan Terorisme ISIS di Indonesia (Universitas Diponegoro). Universitas Diponegoro. Retrieved from http://eprints.undip.ac.id/59382/

Oktorino, N. (2013). Konflik Bersejarah-Greatest Raids. Indonesia: Elex Media Komputindo.

Rahma, A. (2021). Densus 88 Tangkap Otak Perakit Bom Bunuh Diri Gereja Katedral Makassar. Retrieved November 25, 2021, from Tempo website: https://nasional.tempo.co/read/1448123/densus-88-tangkap-otak-perakit-bombunuh-diri-gereja-katedral-makassar

Robiatus, S. (2019). Perempuan Dan Terorisme: Ketidakhadiran Fenomena Female Suicide Terrorism (Fst) Di Indonesia Tahun 2009 - 2015 (Universitas Diponegoro). Universitas Diponegoro. Retrieved from http://eprints.undip.ac.id/75248/

Rosyid, M. (2018). Perempuan dalam Jaringan Radikalisme vis a vis Terorisme Global. Muwazah, 10(2), 162. https://doi.org/10.28918/muwazah.v10i2.1782

Saputro, M. E. (2010). Probabilitas Teroris Perempuan di Indonesia. Jurnal Ilmu Sosial Dan Ilmu Politik, 14(2), 211-228. https://doi.org/10.22146/jsp.10937

Senathalia, A. M., Subhan, Z., \& Rosyidah, I. (2021). Kalam. Kalam: Jurnal Agama Dan Sosial Humaniora, 9(1).

Sjoberg, L., \& Gentry, C., E. (2011). Women, Gender and Terrorism (Studies in Security and International Affairs). United Kingdom: University of Georgia Press United Nations Security Council.

Solihah, R. I. F. (2020). Family Resilience pada Keluarga Pelaku Terorisme (Universitas Negeri Jakarta). Universitas Negeri Jakarta. Retrieved from http://repository.unj.ac.id/4498/

W.kusuma, M. (2002). Terorisme Dalam Perpektif Politik dan Hukum. Jurnal Kriminologi Indonesia, $\quad$ 02(Iii), $22 . \quad$ Retrieved http://journal.ui.ac.id/index.php/jki/article/view/1225

Wijaya, T. I. (2020). Peran Manipulasi Informasi Terhadap Keikutsertaan Perempuan Dalam Gerakan Terorisme. Journal of Terrorism Studies, 2(1). https://doi.org/10.7454/jts.v2i1.1019 